\title{
PEMBERDAYAAN KADER POSYANDU DALAM PENGELOLAAN POSYANDU LANSIA AKTIF DI DESA JETIS SUKOHARJO
}

\author{
Maryatun dan Indarwati \\ Sekolah Tinggi Ilmu Kesehatan 'Aisyiyah Surakarta \\ Email: Tun_Marya@yahoo.com
}

\begin{abstract}
ABSTRAK
Posyandu lansia wilayah Kelurahan Jetis merupakan bentuk kepedulian warga masyarakat terhadap lansia. Banyak perubahan yang terjadi saat menjadi lanjut usia seperti perubahan (fisik, kognitif, mental, spikososial dan spiritual), dengan adanya banyak perubahan tersebut dibutuhkan pelayanan yang lebih optimal. Masalah utama yang dihadapi posyandu lansia ini diantaranya keterbatasan jumlah kader, rendahnya pengetahuan serta keterampilan kader terhadap pelayanan yang diberikan dalam posyandu lansia, terbatasnya fasilitas yang ada di posyandu lansia, kurangnya pengetahuan tentang tertib administrasi di posyandu lansia, serta penguatan kelembagaan sumberdaya manusia bagi kader posyandu lansia. Metode pengabdian masyarakat yang diterapkan adalah dengan pelatihan kader posyandu lansia, penguatan sarana pelayanan posyandu, dan pendampingan pelaksanaan posyandu lansia. Hasil kegiatan pemberdayaan kader posyandu lansia yang dilakukan selama 4 bulan ini, ternyata memberikan kontribusi terhadap pengelolaan pelayanan posyandu lansia dengan sangat bagus. Semula kader belum percaya diri, belum trampil berkomunikasi dan melakukan konseling sederhana tentang kesehatan serta belum trampil membantu bidan dalam administrasi kegiatan, setelah kegiatan pengabdian ini kader lebih percaya diri, trampil dalam berkomunikasi, dan trampil dalam kegiatan administrasi posyandu. Selain peningkatan kemampuan kader tersebut, selepas kegiatan pengabdian masyarakat terbentuk alur posyandu lansia sistem lima meja sehingga proses pelayanan posyandu menjadi lebih tertib dan lancar.
\end{abstract}

Kata kunci: Rumah Ramah Lansia, Posyandu, Lansia

\begin{abstract}
The health service center in Jetis area is a manifestation of the society cares which is proposed to longevity. Many changings occurs when people has become longevity such as changing (in phisics, cognitive, mentality, social psychology, and spiritual), because of those changings, it is needed more optimizely service. The longevity health service center is as a place where becomes friendship space for longevity to obtain the health service and it is being a sharing place for longevity people which means that an appropriate organization for optimizing the quality of life in remaining age so it is expected to increase the expectation of life. The problems faced by the health service center are limited of cadre members, low in cadre's knowledge and skill for service that given in the longevity health service center, limited facilities, less awarness about administration regulation in the longevity health service center and reinforcement in organizing human resource development for cadres in its health service center. Method of society service is applied by implementing the friendly longevity house in
\end{abstract}


health service center activities through training and guiding the cadres in order to help the health center for overcoming problems and also providing the basic counselling material and education for the cadre of the longevity health service center.The result of this study shows that (1) forming the friendly longevity house in health service center, (2) Significantly increasement in cadre's knowledge and skill in managing the longevity health service center: the use of assisting health tools, (3) the cadres are able to apply the administration appropriately,(4) the cadres could do the ecuational counselling. The friendly longevity house increases the quality of health services given by health service center to longevity people.

Keywords: The friendly longevity house, The health service center

\section{PENDAHULUAN}

Menua atau menjadi tua adalah suatu keadaan yang terjadi dalam siklus kehidupan seorang manusia. Kondisi tua merupakan proses alamiah, dimana manusia akan mengalami tiga tahap fase kehidupan dari anak sampai dewasa dan berakhir dengan usia lanjut. Ketiga tahap ini mempunyai perbedaan baik secara biologis ataupun psikologis. Fatimah, (2013) menjelaskan bahwa tahap perkembangan usia tua, seseorang akan mengalami kemunduran secara fisik yang ditandai dengan kurangnya kelenturan kulit, rambut yang semula hitam menjadi memutih, perubahan gigi geligi dan adanya penurunan fungsi panca indera (mata kabur, pendengaran berkurang, berkurangnya sensitivitas rasa)

Pelayanan kesehatan yang disediakan untuk lansia di Indonesia masih sangat terbatas.Usia lanjut merupakan usia yang rawan terhadap berbagai macam penyakit. Pada lansia dengan adanya banyak perubahan (fisik, kognitif, mental, psikososial dan spiritual). Dengan adanya banyak perubahan tersebut, akan menjadi lebih baik jika lansia mendapatkan pelayanan yang lebih baik. Masa tua bukan hanya masa menghadapi sebuah kematian, akan tetapi masa yang seharusnya menyenangkan untuk mempersiapkan akhir kehidupan seseeorang (Bandiyah, 2009). Pelayanan dalam segala aspek bagi lansia di Indonesia, belum mendapatkan sentuhan maksimal dari pemerintah. Kepedulian akan lansia perlu ditumbuhkan sebagai upaya untuk meningkatkan kualitas seseorang di masa tua
Desa Jetis Kabupaten Sukoharjo merupakan wilayah yang melakukan pembinaan dan pelayanan bagi lansia. Rintisan posyandu lansia yang dimulai sejak tahun 2010 sampai sekarang merupakan kepedulian warga akan keberadaan kader lansia di wilayah Kelurahan Jetis serta upaya peningkatan kualitas layanan kesehatan bagi lansia. Namun, Hasil studi pendahuluan ditemukan pelayanan posyandu masih sangat minim, dan pelaksanaannya kurang tertib dan lancar. Terbatasnya kader kesehatan lansia, belum aktifnya kader karena merasa kurang percaya diri, dan hasil wawancara dengan kader lansia, ditemukan data bahwa pengetahuan kader tentang kesehatan serta ilmu pengelolaan posyandu sangat rendah. Sedangkan lansia yang aktif hadir sebanyak 20-35 orang. Selain itu, sistem pelayanan posyandu belum tertata dengan baik dengan lima meja. Dari hasil observasi 3 kader diwilayah Desa Jetis menyebutkan, dalam 1 tahun terakhir pembinaan dari puskesmas hanya 1 kali. Kader juga menyebutkan bahwa, keikutsertaannya dalam pengelolaan posyandu lansia sebenarnya terpaksa. Kader menyebutkan, bahwa permasalahan lansia adalah sangat banyak, baik dari fisik maupun spikologis, dengan keterbatasan ilmu yang dimiliki, kader merasa tidak mampu untuk memberikan pelayanan pada lansia. Kelemahan yang dimiliki dari Posyandu Lansia tersebut secara umum adalah sebagai berikut: (1) Program kegiatan posyandu sudah ada tetapi belum berjalan dengan optimal. (2) Terbatasnya kader kesehatan 
pada posyandu lansia pada kedua mitra. (3) Kurangnya pembinaan pada kader lansia. (4) Kader posyandu belum mampu melayani lansia secara optimal seperti cara menimbang, cara mengukur tinggi badan, cara menuliskan hasil di KMS. Cara mengelola sistem lima meja pelayanan posyandu.

Tujuan dari pemberdayaan ini adalah 1) meningkatnya pengetahuan dan keterampilan kader kesehatan lansia dalam mengelola posyandu, 2) terbentuknya sistem lima meja pelayanan posyandu lansia yang tertib dan lancar, 3) terfasilitasinya alat bantu pemeriksaan lansia seperti timbangan terstandar, sphynomanomater sebagai alat periksa tekanan darah, alat mengukur tinggi badan, serta alat pendokumentasian struktur organisasi dan kegiatan posyandu lansia

\section{METODE}

Kegiatan pengabdian masyarakat ini dilakukan dengan memilih lokasi di Desa Jetis Kabupaten Sukoharjo, dengan pertimbangan masyarakatnya antusias dan lansia aktif ke posyandu sebanyak 20 - 35 orang, namun kader kesehatan terbatas secara kuantitas dan kualitas, selain itu fasilitas posyandu juga masih minim. Dengan permasalahan tersebut, STIKES 'Aisyiyah Surakarta berupaya mengadakan kerjasama dengan pemerintah setempat, untuk melakukan pengabdian masyarakat dengan memberdayakan kader kesehatan lansia serta peningkatan system pelayanan posyandu sehingga ke depannya lebih tertib dan lancar. Kegiatan pengabdian dilakukan selama 5 bulan dari bulan Maret 2016 sampai dengan bulan Juli 2016. Pemberdayaan melibatkan 14 kader posyandu di wilayah Kelurahan Jetis. Beberapa macam kegiatan yang dilakukan yaitu;

1. Pelatihan Kader Posyandu

Pelatihan kader posyandu dilaksanakan selama 2 hari dengan melibatkan narasumber dari Stikes Aisyiyah Surakarta dan Tenaga kesehatan dari Puskesmas Sukoharjo. Kegiatan pengabdian ini juga melibatkan pemangku kebijakan dari unsur tokoh masyarakat dan unsur Kelurahan Jetis serta Puskesmas Sukoharjo.

Materi pelatihan diantaranya adalah 1) mengenal penyakit lansia, 2) konseling dan metode penyuluhan pada lansia, 3) pelaksanaan sistem 5 meja posyandu lansia, 4) senam lansia, 5) teknik pengisian KMS lansia.

2. Pendampingan Kader Posyandu dalam pelaksanaan layanan bagi lansia

Pendampingan pada mitra, dilakukan di lokasi kedua mitra masing masing pada saat pemberian layanan di posyandu lansia. Pendampingan melibatkan mahasiswa STIKES 'Aisyiyah Surakarta. Kegiatan pendampingan posyandu dalam bentuk bimbingan secara langsung dalam menjalankan sistem 5 meja pelayanan posyandu lansia, bimbingan langsung dalam penggunaan alat-alat pelayanan kesehatan seperti cara menggunakan timbangan, cara mengukur tinggi badan, cara mengukur tekanan darah, serta cara melakukan koseling sederhana kepada lansia.

3. Optimalisasi penggunaan sarana prasarana pelayanan posyandu lansia Yang dimaksud dengan optimalisasi disini, adalah dengan pengadaan alat yang memang sangat dibutuhkan seperti lembar balik dan modul tentang penyakit degeneratif dan cara pencegahan serta perawatannya, sphygnomanometer (alat ukur tekanan darah), alat ukur gula darah dan kolesterol. Sedangkan, perawatan alat yang masih bisa difungsikan dengan baik adalah servis timbangan berat badan, perawatan meja dan kursi, serta papan penggumuman untuk pendokumentasian struktur organisasi dan kegiatan posyandu.

\section{HASIL DAN PEMBAHASAN}

Target yang diharapkan dari pemberdayaan kader posyandu lansia dalam pengelolaan posyandu lansia telah terealisasi dengan baik, antara lain:

1. Meningkatnya pengetahuan kader lansia tentang penyakit degeneratif serta 
teknik komunikasi dan konseling dalam memberikan pelayanan kepada lansia.

2. Meningkatnya keterampilan kader kesehatan lansia dalam memberikan konseling sederhana dan pelayanan sistem lima meja posyandu lansia.

3. Meningkatnya keterampilan kader kesehatan lansia dalam penggunaan alat kesehatan, diantaranya cara menimbang berat badan, cara mengukur tinggi badan, cara mengukur tekanan darah.

Kegiatan pemberdayaan pada tahap pertama dalam upaya meningkatkan pengetahuan dan keterampilan kader posyandu lansia adalah pelatihan. Pelatihan dalam pemberdayaan kader posyandu ini dilaksanakan selama 2 hari dengan melibatkan 14 kader posyandu lansia serta pemangku kebijakan dari unsur tokoh masyarakat ( RT, RW), unsur kelurahan( Bayan Kelurahan dan Kepala Kelurahan Jetis dan Kepala Puskesmas Sukoharjo.)

Pelatihan pemberdayaan kader posyandu lansia ini, menjawab permasalahan bahwa kader posyandu lansia di wilayah jetis tersebut sangat dibutuhkan, karena kader dalam melaksanakan kegiatan masih sangat sederhana dan tidak bisa meggunakan alat batu kesehatan dalam upaya pencegahan penyakit yang dapat dicegah melalui promosi kesehatan.

Waktu pelatihan dilaksanakan pada Jumat s/d sabtu Tanggal : 15 s/d 16 April 2016 dari pukul 08.00 sampai dengan pukul 16.00 WIB. Tempat : Rumah Posyandu Ngudi Waras Randu Lawang RT 01 RW 02 Jetis Sukoharjo

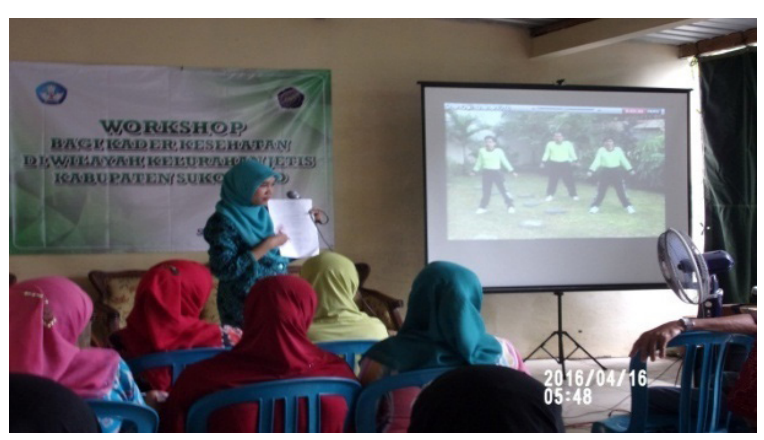

Gb. 1. Mitra sedang mengikuti pelatihan kader Posyandu Lansia
Gambar 1 menunjukan kegiatan pada saat pelatihan bagi kader Posyandu Lansia. Adapun materi-materi yang diberikan pada saat kegiatan pemberdayaan kader posyandu lansia adalah sebagai berikut :

Tabel 1. Materi Pelatihan

\begin{tabular}{|c|c|}
\hline Materi & Kisi Kisi \\
\hline $\begin{array}{l}\text { Mengenal } \\
\text { Penyakit Pada } \\
\text { Lansia }\end{array}$ & $\begin{array}{l}\text { Penyakit yang lazim pada } \\
\text { lansia: Hipertensi, Asam Urat, } \\
\text { DM }\end{array}$ \\
\hline $\begin{array}{l}\text { Senam } \\
\text { Kesehatan } \\
\text { Pada Lansia }\end{array}$ & $\begin{array}{l}\text { Senam Diabetes Militus, } \\
\text { Senam Asma, Senam } \\
\text { Jantung Sehat, Senam Kaki } \\
\text { Diabetikum }\end{array}$ \\
\hline $\begin{array}{l}\text { Pengisian } \\
\text { KMS }\end{array}$ & $\begin{array}{l}\text { Kader dapat melakukan } \\
\text { pengisian KMS setelah } \\
\text { melaksanakan kegiatan } \\
\text { Berat Badan, Tinggi badan, } \\
\text { keluhan-keluhan pada lansia }\end{array}$ \\
\hline $\begin{array}{l}\text { Konseling } \\
\text { dan Metode } \\
\text { Penyuluhan } \\
\text { Pada Lansia }\end{array}$ & $\begin{array}{l}\text { Kader dapat melakukan } \\
\text { penyuluhan sederhana dalam } \\
\text { upaya promosi kesehatan } \\
\text { pada pencegahan penyakit- } \\
\text { penyakit pada lansia }\end{array}$ \\
\hline $\begin{array}{l}\text { Presentasi } \\
\text { Work Shop } \\
\text { (Role Play) }\end{array}$ & Role Play setiap Kelompok \\
\hline $\begin{array}{l}\text { Diskusi } \\
\text { Kelompok }\end{array}$ & $\begin{array}{l}\text { Diskusi permasalahan- } \\
\text { permasalahan dengan } \\
\text { menggunakan kuis }\end{array}$ \\
\hline $\begin{array}{l}\text { Pengelolaan } \\
\text { posyandu } \\
\text { sistem } 5 \text { meja }\end{array}$ & $\begin{array}{l}\text { Alur pelayanan dan bentuk } \\
\text { layanan di masing-masing } \\
\text { meja. }\end{array}$ \\
\hline
\end{tabular}

\section{Pendampingan}

Tahapan selanjutnya, setelah kader mendapatkan pelatihan adalah pendampingan dalam pengelolaan posyandu lansia. Kegiatan pendampingan di posyandu lansia, dimaksudkan untuk memberikan kesempatan kepada kader posyandu lansia untuk dapat mempraktekkan hasil pelatihan yang sudah dilaksanakan sebelumnya. Pendampingan di posyandu lansia dilaksanakan setiap 1 minggu sekali dalam waktu 2,5 bulan. Pendampingan kader posyandu lansia mengupayakan 
dengan melaksanakan kegiatan rutin dengan menerapkan pengetahuan dan keterampilan yang telah diperoleh selama pelatihan.

Setiap hari minggu, lansia mengadakan senam lansia untuk lansia di posyandu Ngudi Waras, sedangkan pada posyandu Bina Sejahtera, kegiatan posyandu dilaksanakan 2 minggu sekali setiap hari sabtu. Pelaksanaan pendampingan pemeriksaan laboratorium dilaksanakan pada sabtu-senin tanggal 2325 April 2016. Pemeriksaan laboratorium dilaksanakan dengan melibatkan puskesmas Sukoharjo. Pemeriksaan ini, sebagai upaya screening bagi lansia dikedua posyandu akan penyakit yang bisa dicegah bagi lansia. Pemeriksaan yang dilaksanakan adalah tensi darah, pemeriksaan laboratorium berupa pemeriksaan gula darah, asam urat, dan kolesterol.

Pada tahap kedua ini, kegiatan melibatkan langsung masyarakat lansia di kedua posyandu yaitu Ngudi Waras dan Bina Sejahtera. Lansia yang dilibatkan sebanyak 114 lansia. Upaya ini, dimaksudkan untuk memberikan gambaran terhadap penyakitpenyakit yang sering menyerang pada usia lanjut.

Dalam kegiatan ini, tim pengusul ipteks bagi masyarakat mengikuti kegiatan dilapangan, yang dilaksanakan oleh kader posyandu lansia di kedua mitra. Kegiatan ini, bertujuan membantu kader posyandu lansia jika dilapangan mengalami kendala terhadap materi-materi yang dilaksanakan dan mengaplikasikan secara langsung kegiatan tersebut pada posyandu lansia masingmasing.

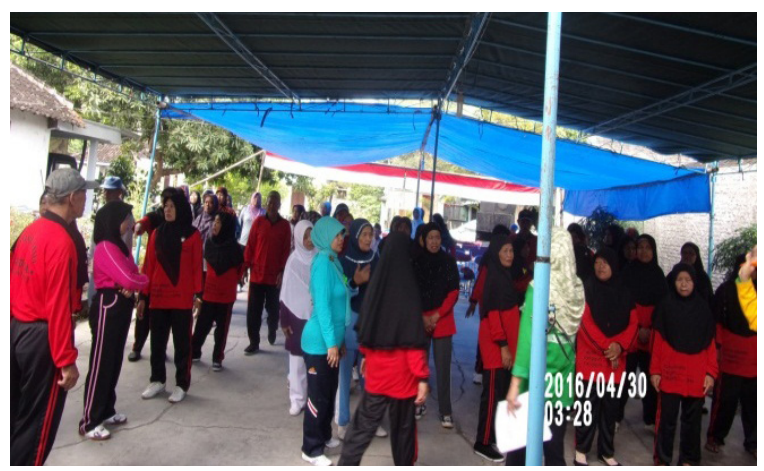

Gb. 2. Mitra sedang mengikuti tahap pendampingan
Gambar 2 adalah tahapan kedua pemberdayaan masyarakat dalam mewujudkan lansia lebih sehat melalui senam lansia. Upaya meningkatkan keterampilan kader, dalam kemampuan melaksanakan gerakan senam pada lansia merupakan upaya inovatif dalam pemberdayaan kader posyandu lansia.

Kader dalam hal ini, diminta membawa lansia diwilayah masing-masing, untuk diberikan pelatihan-pelatihan gerakan senam. Dengan kegiatan ini, kader dituntut mampu menguasai gerakan senam yang diajarkan pada tahap pertama.

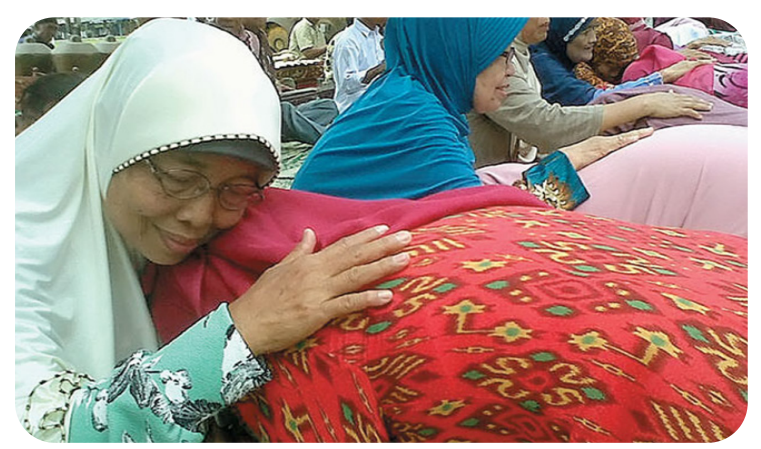

Gb. 3. Upaya inovatif pengembangan posyandu lansia

Dalam gambar 3 merupakan upaya pengembangan posyandu lansia. Kegiatan pemberdayaan ini, berisi acara sungkeman pada lansia oleh putra-putri mereka. Upaya ini, sangat membantu bagi keluarga yang miliki lansia atau masyarakat, sehingga meningkatkan kepedulian terhadap keberadaan lansia

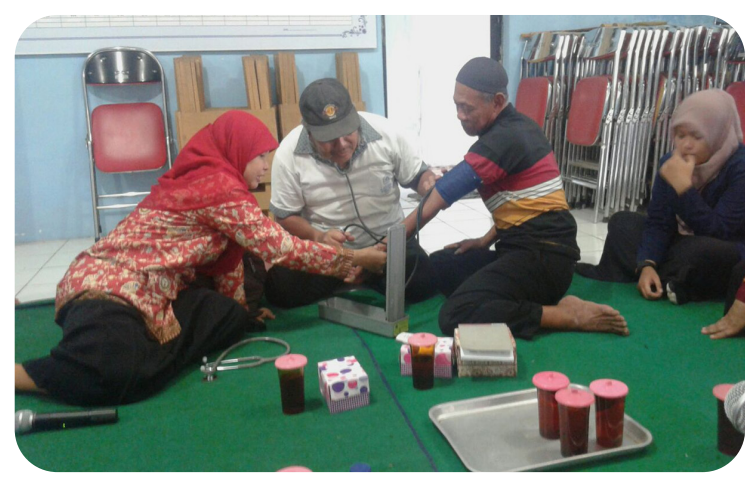

Gb. 4. Upaya inovatif pengembangan kader posyandu lansia dalam penggunaan alat kesehatan 
Gambar 4 merupakan tahapan kedua kegiatan pemberdayaan, yaitu dengan upaya inovatif pengembangan kader posyandu lansia dalam penggunaan alat kesehatan tensi meter, pengukuran suhu tubuh, penggunaan alat pijat sederhana untuk membantu relaksasi bagi lansia.

\section{KESIMPULAN}

Setelah dilakukan pemberdayaan kader posyandu lansia dapat disimpulkan sebagai berikut:

1. Posyandu lansia telah melakukan pelayanan 5 meja dengan tertib dan lancar.

2. Meningkatnya pengetahuan dan keterampilan kader dalam pengelolaan posyandu lansia.

3. Kader posyandu lansia dapat melaksanakan administrasi buku posyandu lansia.

4. Kader posyandu lansia mampu secara minimal melaksanakan konseling edukasi.

5. Kader posyandu lansia mampu menggunakan teknologi alat bantu kesehatan.

\section{SARAN}

Setelah kegiatan pengabdian berlangsung, beberapa saran yang kami sampaikan demi keberlanjutan posyandu lansia adalah sebagai berikut:

1. Kader yang telah dilatih sebaiknya terus mempraktekkan hasil pelatihan dengan didampingi ibu bidan setempat.

2. Perlu perekrutan kader baru dan transfer ilmu ke kader baru tentang materi pelatihan tersebut.

3. Perlu perawatan lebih lanjut alatalat yang digunakan untuk pelayanan posyandu.

4. Hasil pemeriksaan lansia sebaiknya selalu dicatat dalam KMS lansia seperti yang telah diajarkan.

5. Pelaksanaan pelayanan posyandu sebaiknya terus menggunakan sistem 5 meja, agar posyandu bisa tertib dan lancar

\section{PERSANTUNAN}

Pada kesempatan ini, tim penulis menyampaikan ucapan terima kasih kepada Kemenristek Dikti yang telah memberikan kesempatan kepada penulis untuk melaksanakan Hibah pengabdian masyarakat Iptek Bagi Masyarakat (IbM ) Posyandu Lansia di Wilayah Kelurahan Jetis Kabupaten Sukoharjo. Dengan adanya Dana dari Kemenristik Dikti, penulis selaku dosen dapat memberikan peningkatan pengetahuan dan keterampilan bagi kader posyandu lansia diwilayah ini. Sumber Dana ini sangat membantu berjalannya kegiatan dengan lancar sesuai yang kami harapkan.

\section{DAFTAR PUSTAKA}

Azizah, L.M., (2011), Keperawatan lanjut usia, Graha Ilmu, Yogyakarta.

Bandiyah,S.,2009, Lansia dan Keperawatan Gerontik, EGC, Jakarta

Fallen R dan Budi R, (2010), Catatan kuliah keperawatan komunitas, Nuha Medika, Yogyakarta.

Fatimah, 2013, Merawat Manusia Lanjut Usia: Suatu Pendekatan Proses Keperawatan Gerontik, Nuha Medika, Jakarta.

Kementerian Kesehatan RI, (2011), Kecakapan dan Pengasuhan Lansia „Jakarta, Depkes RI.

Kementerian Kesehatan RI, (2013), Kecakapan dan Pengasuhan Lansia, Jakarta, Depkes RI.

Kementrian Kesehatan, R.I., (2012), Pedoman pengelolaan posyandu ,Departemen Kesehatan Republik Indonesia. 